\title{
SOCIAL MEDIA INFLUENCER RESEARCH: A BIBLIOMETRIC ANALYSIS
}

\author{
Shu-Chen Chang \\ Chinese Culture University \\ zsz5@ulive.pccu.edu.tw \\ Chih-Chien Wang \\ National Taipei University \\ wangson@mail.ntpu.edu.tw \\ Chia-Yu Kuo \\ National Taipei University \\ s710836104@gm.ntpu.edu.tw
}

\begin{abstract}
The current study identified research trends and theory regarding social media influencers. By searching journals related to social media influencers in the Social Sciences Citation Index and Sciences Citation Index Expanded database in the 20-year period between January 2000 and December 2019, we collected 237 research articles pertaining to social media influencers. From an analysis of these articles, we mapped research trends and identified highly influential articles. The theories used in social media influencer research were also identified. The results provide fundamental insights into research on social media influencers.
\end{abstract}

Keywords: literature review, social media influencer, social science citation index, SSCI

\section{INTRODUCTION}

Research on social media influencers is a growing field. With the development of the Internet and growth of social media, an increasing number of people communicate, interact, and market themselves or brands on the Internet. To facilitate communication, social media platforms have undergone extensive and rapid developed, which has led to the rise of many Internet celebrities, key opinion leaders, and social media influencers.

Social media influencers are gradually becoming valued in the marketing industry. Marketers use the influence and credibility of social media influencer to promote consumers' attitude and purchase intentions to product and brand. Research on social media influencers has grown over the past decade and has attracted attention from both academics and industry practitioners in various fields.

Previous literature had provided definintion to social media influencers. For example, Freberg, et al. [1] defined social media influencer as "a new type of 
independent third party endorser who shape audience attitudes through blogs, tweets, and the use of other social media." Dhanesh and Duthler [2] defined it as "A person who through personal branding, builds and maintains relationships with multiple followers on social media, and has the ability to inform, entertain, and potentially influence followers' thoughts, attitudes, and behaviors." De Veirman, et al. [3] defined it as "individuals who have developed a sizeable social network of people following them and are viewed a trusted tastemaker in several niches. The common part of these definitions is a person who influences followers or users' attitudes and builds relationship with users through social media. Based on the above definition and recent practice of social media influence marketing, the study propose a definition to social media influencers as "Individuals who has established a personal channel of significant number of subscribers and passionate followers on social media, and with ability to influence their thoughts, attitudes, and behaviors."

"Social media influencer" is a new terminology refers to an individual who has influence in social media. There are similar terms that are related to social media influencers, such as Internet celebrity, opinion leader, and celebrity endorser. Internet celebrity acts as an endorser bridging marketers and consumers together, and generates informative and persuasive content on social media or other online communities to actively engage consumers[4]. Both Internet celebrity and social media influencer are defined in the similar meaning as generating content on social media and being able to influence consumers' attitudes, but social media influencers have interactive relationships with consumers in social media. Bergkvist and Zhou [5] identifies a celebrity endorser is "any individual who enjoys public recognition and who uses this recognition on behalf of a consumer good by appearing with it in an advertisement." The platform is one difference between celebrity endorsers and social media influencers; social media influencers are persuasive in social media, while celebrity endorser increase the persuasive of advertisement in mass media. Besides, social media influencers usually have their own subscribers and passionate followers who can be influenced by social media influencers. When marketers ask social media influencers to endorse their products or brands, social media influences broadcast the message in their social media channels, such as Facebook, Instgram, Twitter, and Youtube. In constrast, celebrity endorsers appear in advertisement as actors or endorsers. The endorsed advertisements can be print advertisements, commercial firms, or anything alike. Marketers spread their budget to boardcast advertisement to consumers. The advertisement become persuasive because the appearance of celebrity.

Opinion leader is another term that with similar meaning to social media influencers. Opinion leaders refer to "individuals who exert an unequal amount of influence on the decisions of others" [6]. Social media influencer can be a kind of opinion leaders. Nevertheless, opinion leader is not necessary be a social media influencer because opinion leaders can be someone in a group of people or in a formal of informal organization. Social media influencers have much more influence on social media. Social media influencers are usually public figures and should be treated as celebrities since social media influencers usually have some subscribers and passionate followers. Opinion leaders can also be public figures, who are named as public opinion leaders. 
Table 1 Definitions of Social Media Influencer, Internet Celebrity, Celebrity Endorser, and Opinion Leader

\begin{tabular}{|c|c|c|}
\hline & Definition & Source \\
\hline \multirow[t]{4}{*}{$\begin{array}{l}\text { Social media } \\
\text { influencer }\end{array}$} & $\begin{array}{l}\text { Individuals with significant number of } \\
\text { subscribers and passionate followers on social } \\
\text { media, and with ability to influence their } \\
\text { thoughts, attitudes, and behaviors. }\end{array}$ & $\begin{array}{l}\text { The current } \\
\text { study (Chang, } \\
\text { Wang, and } \\
\text { Kuo, 2020) }\end{array}$ \\
\hline & $\begin{array}{l}\text { A new type of independent third party endorser } \\
\text { who shape audience attitudes through blogs, } \\
\text { tweets, and the use of other social media. }\end{array}$ & $\begin{array}{l}\text { Freberg, et al. } \\
{[1]}\end{array}$ \\
\hline & $\begin{array}{l}\text { A person who through personal branding, builds } \\
\text { and maintains relationships with multiple } \\
\text { followers on social media, and has the ability to } \\
\text { inform, entertain, and potentially influence } \\
\text { followers' thoughts, attitudes, and behaviors. }\end{array}$ & $\begin{array}{l}\text { Dhanesh and } \\
\text { Duthler [2] }\end{array}$ \\
\hline & $\begin{array}{l}\text { Individuals who have developed a sizeable social } \\
\text { network of people following them and are viewed } \\
\text { a trusted tastemaker in several niches. }\end{array}$ & $\begin{array}{l}\text { De Veirman, } \\
\text { et al. [3] }\end{array}$ \\
\hline $\begin{array}{l}\text { Internet } \\
\text { Celebrity }\end{array}$ & $\begin{array}{l}\text { Internet celebrity acts as an endorser bridging } \\
\text { marketers and consumers together, and generates } \\
\text { informative and persuasive content on social } \\
\text { media or other online communities to actively } \\
\text { engage consumers. }\end{array}$ & $\begin{array}{l}\text { Geng, et al. } \\
{[4]}\end{array}$ \\
\hline $\begin{array}{l}\text { Celebrity } \\
\text { endorser }\end{array}$ & $\begin{array}{l}\text { a celebrity endorser is 'any individual who enjoys } \\
\text { public recognition and who uses this recognition } \\
\text { on behalf of a consumer good by appearing with } \\
\text { it in an } \\
\text { advertisement. }\end{array}$ & $\begin{array}{l}\text { Bergkvist and } \\
\text { Zhou [5] }\end{array}$ \\
\hline Opinion Leader & $\begin{array}{l}\text { Opinion leaders are "individuals who exert an } \\
\text { unequal amount of influence on the decisions of } \\
\text { others" }\end{array}$ & $\begin{array}{l}\text { Flynn, et al. } \\
{[6]}\end{array}$ \\
\hline
\end{tabular}

This study provides a comprehensive understanding of recent trends in social media influencer research. Past research has defined influencers as new, independent third-party endorsers who influence audience attitudes through social media [1]. The current study explored the topics and scope of research on social media influencers. To accomplish this aim, we used bibliometrics to analyze articles published in journals related to social media. To limit our research scope, only journals related to social media influencers listed in the Science Citation Index Expanded (SCIE) or Social Science Citation Index (SSCI) databases were included. The current study used a bibliometric approach to reveal trends in social media influencer research and identify research directions and scope for both academics and practitioners.

This study had two aims: (a) analyze the distribution of articles on social media influencers in terms of publication year, author country, journal, and citation times and (b) analyze the theoretical backgrounds of social media influencer research by using article abstracts. This paper is structured into four sections. The current section 
briefly introduces the study. The second section describes the bibliometric method used in this study. Subsequently, the analytical results are presented. Finally, the article concludes with a discussion of the limitations of this study and implications for future research.

\section{METHODS}

The titles and abstracts of research articles on social media influencers were searched to identify research topics. The SSCI and SCIE databases were searched because of their reputation as leaders among electronic databases of academic literature. We used the terms "influencer" to search the paper titles, abstracts, or keywords. Since some papers used terms "influencer" as a synonyms for independent variable, we limited the search results to articles with the terms of social networks, social media, Facebook, Instagram, or YouTube the paper titles, abstracts, or keywords ${ }^{1}$. Only papers published between 2000 and 2019 were included in the current study.

The current study collected 237 articles. To confine the range of the articles to research articles, only regular articles were selected for bibliometrics. Figure 1 presents the number of articles on social media influencers by year. The number of articles published on social media influencers increased annually and rapidly increased in 2019, when journals related to social media influencers published 99 articles in total.

The current study included articles collected only from the SSCI and SCIE databases. Papers were excluded from the current study if they were not in the SSCI or SCIE databases, even if they were published in the selected journals during the specified period.For example, the International Journal of Advertising has been included in the SSCI database since 2008, meaning that papers published in International Journal of Advertising during or before 2007 were not included in the current study. Furthermore, Journal of Marketing Management has been included in the SSCI database since 2017, meaning that papers published in Journal of Marketing Management during and before 2017 were not included in the current study.

This study explored the development of research on social media influencers by analyzing the 237 identified research articles published in journals related to social media influencers. Although the articles included in the current study were not exhaustive, the current study may serve as a comprehensive base for understanding trends in the field of social media influencers. This study collected the bibliographic data of all 237 articles to determine the distribution of publication years, author countries, journals publishing the articles, and citation times.

\section{RESULTS}

\subsection{Distribution of Publication Years}

\footnotetext{
1 query command for SSCI/SCIE is (TS=("influencer") or TS=( "influencers") ) and (TS=("social network*") or TS=("social media") or TS=("Facebook") or TS=("Instagram") or TS=("YouTube") or TS=("Youtube")) year 1900-2019 DB:

SSCI and SCIE Type: Article
} 
Figure 1 and Table 1 present the annual numbers of research articles on social media influencers published from 2007 to 2019. As revealed in Figure 1, few articles were published before 2010. Nevertheless, more than 10 articles have been published each year since 2014, and the number increased annually from 12 in 2014 to 33 in 2017 and 99 in 2019. The popularity of the Internet and social media has increased the number of social media influencers as well as spurred development in research on them. The increase in research articles on social media influencers reflects the popularity of social media influencers and indicates that researchers are gradually focusing on social media influencers.

A possible reason for the unpopular of social media influencer research before 2006 is that social media service was not popular before 2006. Facebook opened their service to the general public in September 2006 (wikipedia.org/wiki/Facebook). Facebook initialed their service in 2003. However, during 2003 to 2006, Facebook ws a service for students only.

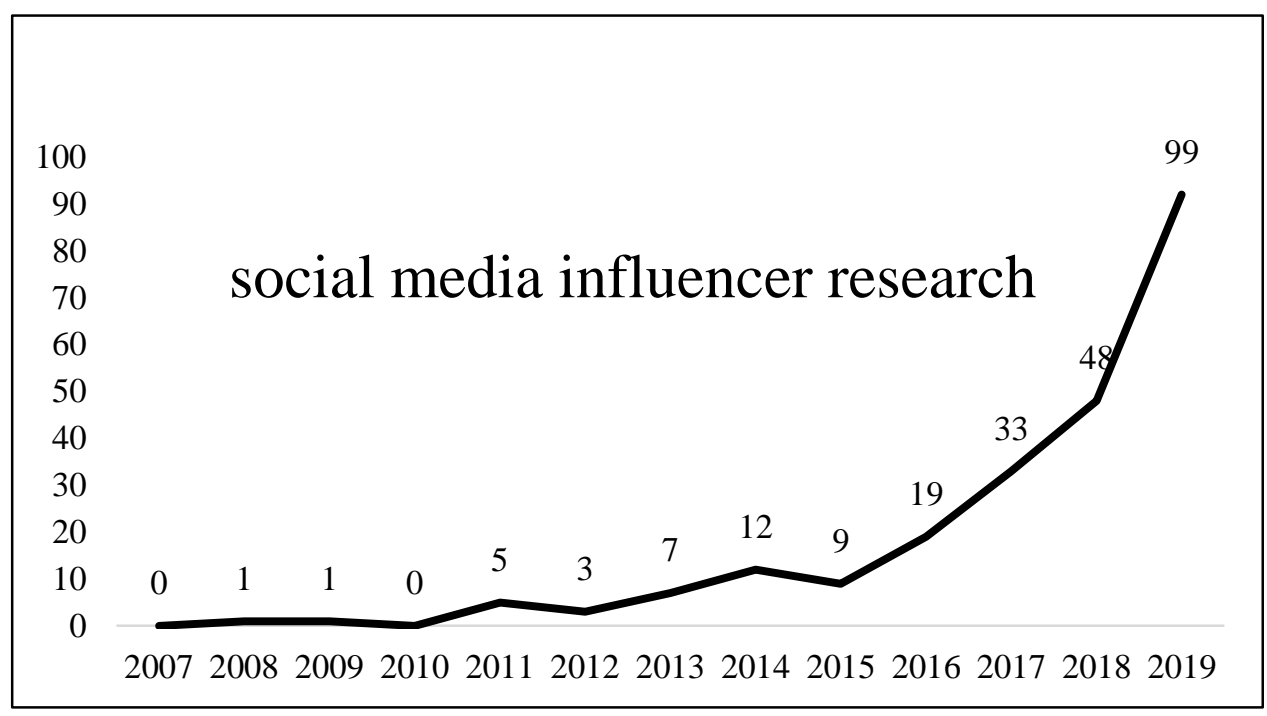

Figure 1. Social media influencer publications, 2007-2019.

\subsection{Distribution of Articles by Journal}

Table 1 presents the distribution of research papers by journal. Many journals have published papers on social media influencers. Table 1 lists the journals that have published more than five articles on social media influencers. In 2011, the International Journal of Advertising and Public Relations Review each published one article on social media influencers but did not publish any relevant articles between 2012 and 2016 in the SSCI database. Most social media influencer research articles were published in Social Media + Society (14 articles), Computers in Human Behavior (7 articles), International Journal of Communication ( 7 articles), International Journal of Advertising (5 articles), and Public Relations Review (5 articles).

\subsection{Distribution of Author Countries}


Table 2 presents the distribution of author countries for the 237 social media influencer studies. The countries that published the most research on social media influencers between 2004 and 2019 were identified by author affiliation. The five most prolific countries in social media influencer research were the United Kingdom (42.62\%), the United States (34.60\%), the Netherlands (12.24\%), Switzerland $(4.64 \%)$, and Canada $(2.11 \%)$. Scholars from these countries have interest and play a central role in social media influencer research.

Table 2. Social Media Influencer Publications by Journal

\begin{tabular}{|c|c|c|c|c|c|}
\hline & $\begin{array}{l}\text { Social } \\
\text { Media }+ \\
\text { Society }\end{array}$ & $\begin{array}{l}\text { Computers } \\
\text { in Human } \\
\text { Behavior }\end{array}$ & $\begin{array}{c}\text { International } \\
\text { Journal of } \\
\text { Communication }\end{array}$ & $\begin{array}{l}\text { International } \\
\text { Journal of } \\
\text { Advertising }\end{array}$ & $\begin{array}{l}\text { Public } \\
\text { Relations } \\
\text { Review }\end{array}$ \\
\hline 2010 & & & & & \\
\hline 2011 & & & & 1 & 1 \\
\hline 2012 & & & & & \\
\hline 2013 & & & & & \\
\hline 2014 & & & & & \\
\hline 2015 & & 2 & & & \\
\hline 2016 & 2 & 2 & & & \\
\hline 2017 & 2 & 1 & 2 & 3 & 1 \\
\hline 2018 & 2 & 1 & 1 & & 1 \\
\hline 2019 & 8 & 1 & 4 & 1 & 2 \\
\hline Subtotal & 14 & 7 & 7 & 5 & 5 \\
\hline
\end{tabular}

Note: Journals with more than five articles are listed.

Table 3. Social Media Influencer Publications by Country

\begin{tabular}{lcc}
\hline COUNTRYS & Articles & Percentage (\% of 237) \\
\hline United Kingdom & 101 & $42.6 \%$ \\
United States & 82 & $34.6 \%$ \\
Netherlands & 29 & $12.2 \%$ \\
Switzerland & 11 & $4.6 \%$ \\
Canada & 5 & $2.1 \%$ \\
Spain & 2 & $0.8 \%$ \\
New Zealand & 1 & $0.4 \%$ \\
Germany & 1 & $0.4 \%$ \\
Czech Republic & 1 & $0.4 \%$ \\
Croatia & 1 & $0.4 \%$ \\
China & 1 & $0.4 \%$ \\
Ireland & 1 & $0.4 \%$ \\
Japan & 1 & $0.4 \%$ \\
\hline
\end{tabular}


Table 3 lists highly influential research articles on social media influencers. A total of 22 articles have received more than 30 citations. An article published by Katona (2011) has been cited 208 times. The article by Kiss and Bichler (2008) has received 108 citations. Dubois and Gaffney's (2014) article has been cited 85 times. These 22 highly influential articles on social media influencers were published in 18 different journals.

Table 4. Highly Influential Research Articles on Social Media Influencers, 2006-2019

\begin{tabular}{|c|c|c|c|c|}
\hline Authors & Years & Article Title & Journal & $\begin{array}{l}\text { Cited } \\
\text { Times }\end{array}$ \\
\hline$[7]$ & 2011 & $\begin{array}{l}\text { Network Effects and Personal } \\
\text { Influences: The Diffusion of an } \\
\text { Online Social Network }\end{array}$ & $\begin{array}{l}\text { Journal Of } \\
\text { Marketing Research }\end{array}$ & 208 \\
\hline$[8]$ & 2008 & $\begin{array}{l}\text { Identification of influencers - } \\
\text { Measuring influence in } \\
\text { customer networks }\end{array}$ & $\begin{array}{l}\text { Decision Support } \\
\text { Systems }\end{array}$ & 182 \\
\hline [9] & 2014 & $\begin{array}{l}\text { The Multiple Facets of } \\
\text { Influence: Identifying Political } \\
\text { Influentials and Opinion } \\
\text { Leaders on Twitter }\end{array}$ & $\begin{array}{l}\text { American } \\
\text { Behavioral Scientist }\end{array}$ & 85 \\
\hline [1] & 2011 & $\begin{array}{l}\text { Who are the social media } \\
\text { influencers? A study of public } \\
\text { perceptions of personality }\end{array}$ & $\begin{array}{l}\text { Public Relations } \\
\text { Review }\end{array}$ & 85 \\
\hline$[10]$ & 2012 & $\begin{array}{l}\text { Increasing the ROI of Social } \\
\text { Media Marketing }\end{array}$ & $\begin{array}{l}\text { MIT Sloan } \\
\text { Management Review }\end{array}$ & 80 \\
\hline$[11]$ & 2017 & $\begin{array}{l}\text { Self-branding, 'micro-celebrity' } \\
\text { and the rise of Social Media } \\
\text { Influencers }\end{array}$ & Celebrity Studies & 79 \\
\hline$[12]$ & 2009 & $\begin{array}{l}\text { Influencing the influencers: a } \\
\text { theory of strategic diffusion }\end{array}$ & $\begin{array}{l}\text { Rand Journal Of } \\
\text { Economics }\end{array}$ & 79 \\
\hline$[3]$ & 2017 & $\begin{array}{l}\text { Marketing through Instagram } \\
\text { influencers: the impact of } \\
\text { number of followers and } \\
\text { product divergence on brand } \\
\text { attitude }\end{array}$ & $\begin{array}{l}\text { International Journal } \\
\text { Of Advertising }\end{array}$ & 77 \\
\hline [13] & 2016 & $\begin{array}{l}\text { Aren't These Just Young, Rich } \\
\text { Women Doing Vain Things } \\
\text { Online?: Influencer Selfies as } \\
\text { Subversive Frivolity }\end{array}$ & $\begin{array}{l}\text { Social Media + } \\
\text { Society }\end{array}$ & 69 \\
\hline [14] & 2014 & $\begin{array}{l}\text { Personalized news } \\
\text { recommendation via implicit } \\
\text { social experts }\end{array}$ & Information Sciences & 67 \\
\hline$[15]$ & 2011 & $\begin{array}{l}\text { Drivers of new product } \\
\text { recommending and referral } \\
\text { behaviour on social network } \\
\text { sites }\end{array}$ & $\begin{array}{l}\text { International Journal } \\
\text { Of Advertising }\end{array}$ & 67 \\
\hline
\end{tabular}

Table 4. Highly Influential Research Articles on Social Media Influencers, 2006-2019 (cont.) 


\begin{tabular}{|c|c|c|c|c|}
\hline Authors & Years & Article Title & Journal & $\begin{array}{l}\text { Cited } \\
\text { Times }\end{array}$ \\
\hline [16] & 2016 & $\begin{array}{l}\text { Collective Influence Algorithm } \\
\text { to find influencers via optimal } \\
\text { percolation in massively large } \\
\text { social media }\end{array}$ & Scientific Reports & 57 \\
\hline [17] & 2016 & $\begin{array}{l}\text { Visibility labour: Engaging } \\
\text { with Influencers' fashion } \\
\text { brands and \#OOTD advertorial } \\
\text { campaigns on Instagram }\end{array}$ & $\begin{array}{l}\text { Media International } \\
\text { Australia }\end{array}$ & 55 \\
\hline [18] & 2011 & $\begin{array}{l}\text { Discovering influencers for } \\
\text { marketing in the blogosphere }\end{array}$ & Information Sciences & 48 \\
\hline [19] & 2013 & $\begin{array}{l}\text { Multi-stage complex } \\
\text { contagions }\end{array}$ & Chaos & 47 \\
\hline$[20]$ & 2014 & $\begin{array}{l}\text { IDENTIFYING AND } \\
\text { VERIFYING NEWS } \\
\text { THROUGH SOCIAL MEDIA } \\
\text { Developing a user-centred tool } \\
\text { for professional journalists }\end{array}$ & Digital Journalism & 45 \\
\hline [21] & 2015 & $\begin{array}{l}\text { Identifying effective } \\
\text { influencers based on trust for } \\
\text { electronic word-of-mouth } \\
\text { marketing: A domain-aware } \\
\text { approach }\end{array}$ & Information Sciences & 39 \\
\hline [22] & 2014 & $\begin{array}{l}\text { Topic-Sensitive Influencer } \\
\text { Mining in Interest-Based } \\
\text { Social Media Networks via } \\
\text { Hypergraph Learning }\end{array}$ & $\begin{array}{l}\text { IEEE Transactions } \\
\text { On Multimedia }\end{array}$ & 38 \\
\hline [23] & 2017 & $\begin{array}{l}\text { Virtual makeover: Selfie-taking } \\
\text { and social media use increase } \\
\text { selfie-editing frequency } \\
\text { through social comparison }\end{array}$ & $\begin{array}{l}\text { Computers In } \\
\text { Human Behavior }\end{array}$ & 37 \\
\hline$[24]$ & 2014 & $\begin{array}{l}\text { Social media: A tool to spread } \\
\text { information: A case study } \\
\text { analysis of Twitter } \\
\text { conversation at the Cardiac } \\
\text { Society of Australia a New } \\
\text { Zealand } 61 \text { st Annual Scientific } \\
\text { Meeting } 2013\end{array}$ & Collegian & 37 \\
\hline$[25]$ & 2017 & $\begin{array}{l}\text { Modeling the role of message } \\
\text { content and influencers in } \\
\text { social media rebroadcasting }\end{array}$ & $\begin{array}{l}\text { International Journal } \\
\text { Of Research In } \\
\text { Marketing }\end{array}$ & 31 \\
\hline$[26]$ & 2015 & $\begin{array}{l}\text { Information disclosure on } \\
\text { social networking sites: An } \\
\text { intrinsic-extrinsic motivation } \\
\text { perspective }\end{array}$ & $\begin{array}{l}\text { Computers In } \\
\text { Human Behavior }\end{array}$ & 31 \\
\hline
\end{tabular}

Note: Citation times was count in July 2020.

\subsection{Distribution of Research Areas}


Figure 2 reveals the distribution of research areas for social media influencer articles. The five areas that published the most articles were communication (60 articles), business and economics (54 articles), computer science (51 articles), psychology (20 articles), and information science and library science (14 articles). Therefore, we inferred that the current social media influencer articles have influence in the fields of communication, followed by business and economics, computer science, and psychology. Other areas have fewer articles on social media influencers but remain valuable for research.

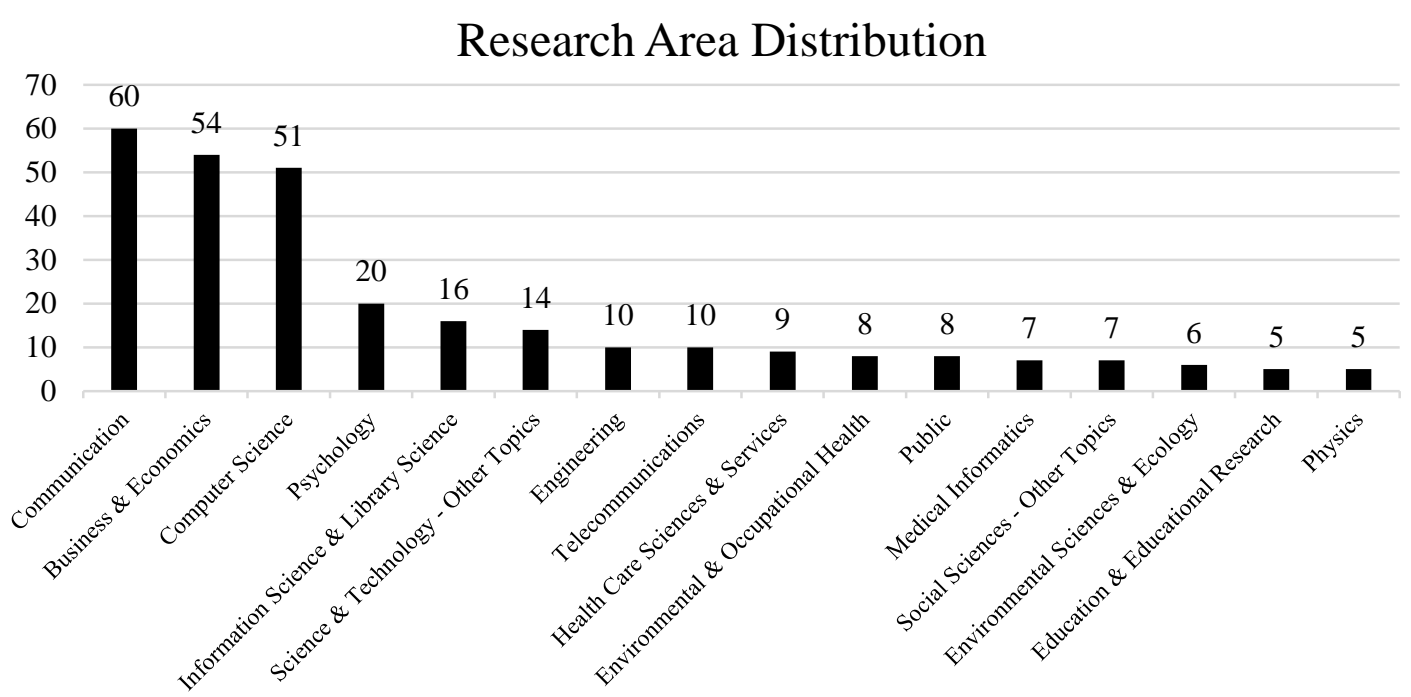

Figure 2. Distribution of social media influencer articles by research area.

\subsection{Theoretical Backgrounds of Articles on Social Media Influencers}

The keywords of academic articles can help others locate them rapidly. Most journals request that authors provide keywords for their articles. These keywords are typically highly relevant to the focus of the article. Thus, some articles include the applied theories in the keywords. In the current study, all the keywords of the 237 research articles on social media influencers were evaluated to identify their theoretical backgrounds.

From a keyword review, we identified the theories used in social media influencer research (Table 4). Some theories used the term "model" instead of "theory." Theories without the term "theory" in their names were included in the list. However, not all keywords containing "theory" or "model" were included in the theory list. In addition, the list in Table 4 does not include theories or models related to algorithms or theories used for data analysis. We evaluated terms individually to ensure that all items in Table 4 were theoretical. Not all authors included the theories they used in the keywords because most journals allow authors to provide only 5-10 keywords for their articles. Thus, Table 4 does not include all theories used in social media influencer research. Nevertheless, Table 4 remains useful because it can serve as a reading list for novices in social media influencer research. 
After collecting and analyzing the keywords of all articles, we sorted them by frequency. The most common keywords were social media (73 occurrences) and influencers (43 occurrences). The social media platform most frequently appearing in keywords was Twitter (28 occurrences), followed by Instagram (19 occurrences) and YouTube (10 occurrences). Thus, researchers have demonstrated some interest in influencers on Twitter or have focused on this platform to conduct more in-depth research.

Table 5. Theories Used in Social Media Influencer Research Articles, 2000-2019

\begin{tabular}{cccc}
\hline Game Theory & Emotion Models & Integrated Model & $\begin{array}{c}\text { Technology } \\
\text { Acceptance Model }\end{array}$ \\
\hline $\begin{array}{c}\text { Network } \\
\text { Theory }\end{array}$ & $\begin{array}{c}\text { Graph Modelling and } \\
\text { Graphical Model }\end{array}$ & $\begin{array}{c}\text { Linear Threshold } \\
\text { Diffusion Model }\end{array}$ & $\begin{array}{c}\text { The Reciprocal Model } \\
\text { Of Information Flow }\end{array}$ \\
\hline $\begin{array}{c}\text { Practice } \\
\text { Theory }\end{array}$ & $\begin{array}{c}\text { susceptible-infected-ack } \\
\text { nowledged-loathmodel } \\
\text { (SIALS Model) }\end{array}$ & $\begin{array}{c}\text { Regression } \\
\text { Modelling }\end{array}$ & $\begin{array}{c}\text { Topic Model } \\
\text { \& Topic Modeling }\end{array}$ \\
\hline $\begin{array}{c}\text { Uses And } \\
\text { Gratifications } \\
\text { Theory }\end{array}$ & $\begin{array}{c}\text { Influence Model and } \\
\text { Influential Model }\end{array}$ & $\begin{array}{c}\text { Semantic } \\
\text { Modelling }\end{array}$ & User Modeling \\
\hline Voter Model & & & \\
\hline
\end{tabular}

Table 6. Keywords of Social Media Influencer Research Articles, 2000-2019

\begin{tabular}{lc}
\hline Keywords & Times \\
\hline Social media & 73 \\
Influencer(s) & 41 \\
Twitter & 28 \\
Social network analysis & 21 \\
Instagram & 19 \\
Social network(s) & 29 \\
Influencer marketing & 12 \\
Social media influencer(s) & 16 \\
YouTube & 10 \\
Social influence & 9 \\
Social media marketing & 7 \\
Influence & 6 \\
Influence maximization & 6 \\
Information diffusion & 6 \\
Viral marketing & 6 \\
Facebook & 6 \\
Microcelebrity & 5 \\
\hline Note: Keywordsused & 5 \\
\hline
\end{tabular}

Note: Keywords used more than five times are listed. 


\section{DISCUSSION}

This paper presents the findings of a bibliometric study of research articles on social media influencers published in 158 journals listed in the SSCI and SCIE databases. A total of 237 social media influencer research articles published in the period of 2000 to 2019 were collected. We identified highly influential articles in social media influencer research and the theoretical backgrounds of social media influencer research.

Although the current study offers informative insights into the knowledge structure of social media influencer research, it has some limitations. First, we included only articles related to social media influencers published in the SSCI or SCIE databases, which may have influenced the generalizability of the study. In addition, only the keywords of articles were reviewed to identify the theoretical backgrounds of social media influencer research. Many articles did not specify the theories used in the keywords. Thus, it is likely that not all of the theories used in social media influencer research were included in our list.

However, we still trust that this study provides a valuable integration of social media influencer research as well as a different perspective. We believe that the current study provides a useful briefing for newcomers to the field.

\section{REFERENCE}

[1] K. Freberg, K. Graham, K. McGaughey, and L. A. Freberg, "Who are the social media influencers? A study of public perceptions of personality," Public Relations Review, vol. 37, no. 1, pp. 90-92, 2011.

[2] G. S. Dhanesh and G. Duthler, "Relationship management through social media influencers: Effects of followers' awareness of paid endorsement," Public Relations Review, vol. 45, no. 3, p. 101765, 2019.

[3] M. De Veirman, V. Cauberghe, and L. Hudders, "Marketing through Instagram influencers: the impact of number of followers and product divergence on brand attitude," International Journal of Advertising, vol. 36, no. 5, pp. 798-828, 2017.

[4] R. Geng, S. Wang, X. Chen, D. Song, and J. Yu, "Content marketing in e-commerce platforms in the internet celebrity economy," Industrial Management \& Data Systems, 2020.

[5] L. Bergkvist and K. Q. Zhou, "Celebrity endorsements: a literature review and research agenda," International Journal of Advertising, vol. 35, no. 4, pp. 642-663, 2016.

[6] L. R. Flynn, R. E. Goldsmith, and J. K. Eastman, "Opinion leaders and opinion seekers: Two new measurement scales," Journal of the academy of marketing science, vol. 24, no. 2, p. 137, 1996.

[7] Z. Katona, P. P. Zubcsek, and M. Sarvary, "Network effects and personal influences: The diffusion of an online social network," Journal of Marketing Research, vol. 48, no. 3, pp. 425-443, 2011.

[8] C. Kiss and M. Bichler, "Identification of influencers - measuring influence in customer networks," Decision Support Systems, vol. 46, no. 1, pp. 233-253, 2008.

[9] E. Dubois and D. Gaffney, "The multiple facets of influence: Identifying political influentials and opinion leaders on Twitter," American Behavioral Scientist, vol. 58, no. 10, pp. 1260-1277, 2014.

[10] V. Kumar and R. Mirchandani, "Increasing the ROI of social media marketing," MIT sloan management review, vol. 54, no. 1, p. 55, 2012.

[11] S. Khamis, L. Ang, and R. Welling, "Self-branding, 'micro-celebrity'and the rise of Social Media Influencers," Celebrity studies, vol. 8, no. 2, pp. 191-208, 2017. 
[12] A. Galeotti and S. Goyal, "Influencing the influencers: a theory of strategic diffusion," The RAND Journal of Economics, vol. 40, no. 3, pp. 509-532, 2009.

[13] C. Abidin, "“Aren't these just young, rich women doing vain things online?": Influencer selfies as subversive frivolity," Social Media+ Society, vol. 2, no. 2, p. $2056305116641342,2016$.

[14] C. Lin, R. Xie, X. Guan, L. Li, and T. Li, "Personalized news recommendation via implicit social experts," Information Sciences, vol. 254, pp. 1-18, 2014.

[15] P. Chatterjee, "Drivers of new product recommending and referral behaviour on social network sites," International Journal of Advertising, vol. 30, no. 1, pp. 77-101, 2011.

[16] F. Morone, B. Min, L. Bo, R. Mari, and H. A. Makse, "Collective influence algorithm to find influencers via optimal percolation in massively large social media," Scientific reports, vol. 6, p. 30062, 2016.

[17] C. Abidin, "Visibility labour: Engaging with Influencers' fashion brands and\# OOTD advertorial campaigns on Instagram," Media International Australia, vol. 161, no. 1, pp. 86-100, 2016.

[18] Y.-M. Li, C.-Y. Lai, and C.-W. Chen, "Discovering influencers for marketing in the blogosphere," Information Sciences, vol. 181, no. 23, pp. 5143-5157, 2011.

[19] S. Melnik, J. A. Ward, J. P. Gleeson, and M. A. Porter, "Multi-stage complex contagions," Chaos: An Interdisciplinary Journal of Nonlinear Science, vol. 23, no. 1, p. 013124, 2013.

[20] S. Schifferes, N. Newman, N. Thurman, D. Corney, A. Göker, and C. Martin, "Identifying and verifying news through social media: Developing a user-centred tool for professional journalists," Digital journalism, vol. 2, no. 3, pp. 406-418, 2014.

[21] S. Liu, C. Jiang, Z. Lin, Y. Ding, R. Duan, and Z. Xu, "Identifying effective influencers based on trust for electronic word-of-mouth marketing: A domain-aware approach," Information sciences, vol. 306, pp. 34-52, 2015.

[22] Q. Fang, J. Sang, C. Xu, and Y. Rui, "Topic-sensitive influencer mining in interest-based social media networks via hypergraph learning," IEEE Transactions on Multimedia, vol. 16, no. 3, pp. 796-812, 2014.

[23] J. Chae, "Virtual makeover: Selfie-taking and social media use increase selfie-editing frequency through social comparison," Computers in Human Behavior, vol. 66, pp. 370-376, 2017.

[24] C. Ferguson, S. C. Inglis, P. J. Newton, P. J. Cripps, P. S. Macdonald, and P. M. Davidson, "Social media: a tool to spread information: a case study analysis of twitter conversation at the Cardiac Society of Australia \& New Zealand 61st annual scientific meeting 2013," Collegian, vol. 21, no. 2, pp. 89-93, 2014.

[25] Y. Zhang, W. W. Moe, and D. A. Schweidel, "Modeling the role of message content and influencers in social media rebroadcasting," International Journal of Research in Marketing, vol. 34, no. 1, pp. 100-119, 2017.

[26] J. Shibchurn and X. Yan, "Information disclosure on social networking sites: An intrinsic-extrinsic motivation perspective," Computers in Human Behavior, vol. 44, pp. 103-117, 2015. 